\title{
Distribution and Detection of Cowpea Viruses Infecting Cowpea in Uganda
}

\author{
Martin Orawu*, John Obuo, Robert Omadi \\ National Semi-Arid Resources Research Institute, Private Bag, Soroti, Uganda \\ Email: *orawum@gmail.com \\ Received 15 January 2015; accepted 8 March 2015; published 11 March 2015 \\ Copyright (C) 2015 by authors and Scientific Research Publishing Inc. \\ This work is licensed under the Creative Commons Attribution International License (CC BY). \\ http://creativecommons.org/licenses/by/4.0/

cC) (i) Open Access

\begin{abstract}
Cowpea viruses are economically important diseases of cowpea in the major growing areas of Uganda and have inflicted negatively on food security, nutrition and income for many households. The objective of the study was to determine the prevalence and identity of viruses infecting cowpea in the growing districts of Uganda. Surveys were conducted in the field of grown cowpea, and virus symptoms were recorded on the basis of virus incidence and severity in the districts of Apac, Lira, Pader and Kumi. Symptomatic virus leaf samples were also collected from the same fields surveyed for serological test for detection of virus types using antibodies to cowpea aphid-borne mosaic virus (CABMV), cowpea mild mottle virus (CPMMV), cowpea severe mosaic virus (CPSMV), cowpea mosaic virus (CPMV), cowpea chlorotic mottle virus (CPCMV), cucumber mosaic virus (CMV) and cowpea chlorotic mosaic virus (CCMV) in double antibody sandwich enzyme-linked immunosorbent assay (DAS-ELISA). Results showed that there was the highest percentage of incidence and severity in Kumi $(85.4 \%$ and $13.8 \%$, respectively) with the lowest percentage of incidence and severity observed in Apac (55.9\% and 4.7\%, respectively). Serological test revealed the presence of CABMV, CPMMV, CPSMV and CMV in the leaf samples as the major virus types in the surveyed districts. However, CPCMV, CPMV and CCMV were not detected in the leaf samples surveyed in the cowpea growing districts. Serological test also revealed that among the virus types detected, single and multiple virus types occurred in the plant samples. The highest single virus type occurring in the plant samples was CPMMV (11.6\%) and the lowest was CABMV (1.8\%). The virus types namely CMV, CABMV, CPMMV and CPSMV occurred in combinations with proportion of $7.1 \%$ in the infected plant samples. Therefore, this information obtained on the virus types provides an opportunity for breeders to develop cowpea variety with multiple resistance genes to control several virus types infecting cowpea.
\end{abstract}

\section{Keywords}

Cowpea, Incidence, Serology, Virus Types

\footnotetext{
${ }^{*}$ Corresponding author.
} 


\section{Introduction}

Cowpea crop is one of the most widely adapted and nutritious food legume crops in the tropics and subtropics of Africa. The crop has considerable adaptation to drought compared to other legume crops notably beans, groundnuts and soybeans. Dry grain for human consumption is the principal product of the cowpea plant, and leaves, fresh peas and fresh pods are equally consumed [1]. Ehlers and Hall [1] showed that farmers in California can achieve up to dry grain yields of $4000 \mathrm{~kg} / \mathrm{ha}$ of improved cowpea varieties with good resistance to virus diseases. In the case of Uganda, where the crop is intensively cultivated in the northern and eastern regions, farmers attain the yield of less than $200 \mathrm{~kg} / \mathrm{ha}$ due to susceptible cultivar (Ebelat) which is ravaged by virus infection [2] [3]. It is estimated that up to $100 \%$ yield losses in field grown with susceptible cowpea cultivar can be observed depending on the virus-host vector relationships, as well as prevailing epidemiological factors [4]. In Uganda, cowpea viruses have become a major problem in the cowpea growing regions and cause a great effect on production, consequently affecting the household livelihoods.

Symptoms of plant virus diseases have been recognized and documented, although it has only recently become possible to identify and study the causal pathogens. The most damaging diseases for cowpea are caused by viruses and represent significant proportion of losses regarding the potential value of the crop in sub-Saharan Africa [5]. Cowpea plants are often infected by more than one virus disease, resulting in serious economic losses in agricultural production [6]. The economically important viruses in Africa include cowpea chlorotic mottle virus (CPCMV), cowpea severe mosaic virus (CPSMV), cowpea aphid-borne mosaic virus (CABMV), cowpea mild mottle virus (CPMMV), cowpea mosaic virus (CPMV), cucumber mosaic virus (CMV) and cowpea chlorotic mosaic virus (CCMV) [5] [7]. In the case of Uganda, the important viruses have not been established and yet such information is vital to the nation to establish the identity of the viruses that affect cowpea production. This type of information can help the plant breeders to formulate a strategy to mitigate effects resulting from virus infections through breeding with multiple resistant cowpea varieties. The occurrence of viral diseases varies from region to region depending on factors such as population dynamics of virus vectors, climatic conditions and virus inoculums level [8]. Disease symptoms caused by viruses vary in nature, but the most common symptoms include mosaic, chlorotic leaf, leaf distortion, leaf mottling and stunting of plants.

Different strains of viruses can be detected using a number of different methods based on the comparison of type and severity of symptoms on a range of test plants, either by serology, immuno-electrophoresis or by enzyme-linked immunosorbent sandwich assay (ELISA) tests. Immunosorbent assays (DAS-ELISA) for instance are widely applied in the detection of numerous plant viruses because of their sensitivity and reliability but require obtaining results only in two days [9] [10]. The double antibody sandwich ELISA uses antibodies which are bound to the surface of a micro-titre plate to capture the antigen of interest. A specific antibody-enzyme conjugate is then used to detect the trapped antigen. The presence of the antigen in infected sap is indirectly detected through a colorimetric substrate reaction that develops because of the reaction of an enzyme (e.g. alkaline phosphatase) conjugated to antibodies in the presence of an appropriate substrate (p-nitrophenylphosphate, tetrametylbenzidine) [11]. Detection assay has been used to obtain quantitative data with promising results, but this approach is laborious because of the several steps you undergo to finally detect the virus types [12]. The information on viruses is vital for purposes of planning when searching for control strategies. Therefore, the objective of this study was to determine the prevalence and identity of viruses infecting cowpea in Uganda.

\section{Materials and Methods}

\subsection{Survey and Sampling Areas}

Field surveys were conducted in the cowpea growing districts of Apac, Lira, Pader and Kumi in the farmers' fields during 2010. The surveys were undertaken in the second season (August-December) where the cowpea crop is heavily cultivated by farmers in Uganda. The surveys were carried out when the cowpea crop was at its vegetative growth stage. Seven distant fields approximately $5 \mathrm{~km}$ apart were selected and surveys carried out in each district growing cowpea (Ebelat) cultivar. The fields and districts were taken into consideration to determine whether there were variations in virus occurrence amongst districts or fields or across districts or fields. At the same time, plant leaf samples with symptomatic virus infection were collected from each sampled plot in farmers' fields for double antibody enzyme-linked immunosorbent assay (DAS-ELISA) test. The four sampled plots in each field were treated as replicates in each district. Four sampling plots each measuring $3 \times 3 \mathrm{~m}$ in the 
different points in each field per field were carried out, and the total number of plants within each plot was counted to estimate the percentage of diseased plants with virus symptoms. The plant leaves within the plot were sampled for virus symptoms and 28 plant leaf samples from each district were collected. A total of 112 virus symptomatic leaf samples were collected from the four districts of Apac, Lira, Pader and Kumi.

\subsection{Disease Assessment}

Assessment of virus symptoms was based on percentage incidence and severity. Disease incidence was calculated by expressing the number of plants with virus symptoms as a percentage of the total number of plants in each sampled plot area of $3 \times 3 \mathrm{~m}$. Disease severity was assessed on cowpea leaves with virus symptoms and this was done visually based on the following standard rating scale: where $1=0 \%$ (no virus symptoms) and $5 \geq$ $60 \%$ (very severe symptoms and death of the plants) [13].

\subsection{Data Analysis}

The data on disease ratings were subjected to GenStat $15^{\text {th }}$ edition for analysis of variance, using the following model: $\mathbf{Y}_{\mathrm{ijk}}=\boldsymbol{\mu}+\mathbf{r}_{\mathbf{i}}+\mathbf{d}_{\mathbf{j}}+\mathbf{f}_{\mathbf{k}}+(\mathbf{d} / \mathbf{f})_{\mathbf{j k}}+\boldsymbol{\varepsilon}_{\mathrm{ijk}}$; where: $\mathrm{Y}_{\mathrm{ijk}}$ is the level of the virus symptoms/infection observed at the $\mathrm{ijk}^{\text {th }}$ location; $\mu$ is the overall mean observed for virus symptoms/infection; $\mathrm{r}_{\mathrm{i}}$ is the level of virus symptom/infection observation at $\mathrm{i}^{\text {th }}$ plot (area randomly sampled); $d_{j}$ is the level of virus symptom/infection observation at $\mathrm{j}^{\text {th }}$ district; $\mathrm{f}_{\mathrm{k}}$ is the level of virus symptom/infection observation at $\mathrm{k}^{\text {th }}$ field in the sub-counties; $\mathrm{d} / \mathrm{f}_{\mathrm{jk}}$ is the level of virus symptom/infection observation at $\mathrm{jk}^{\text {th }}$ field nested in district and $\varepsilon_{\mathrm{ijk}}$ is the error term associated with each observation.

\subsection{Laboratory Testing of Leaf Samples Using Double Antibody Sandwich Enzyme-Linked Immunosorbent Assay (DAS-ELISA)}

In the study, cowpea leaf samples were collected from four cowpea growing districts and subjected to DASELISA tests by using seven antisera kits specific to CABMV, CPCMV, CPMMV, CPMV, CMV, CPSMV and CCMV in the Biotech laboratory in the Department of Crop Science at Makerere University, Kampala, Uganda. Plant leaf samples exhibiting virus symptoms collected from different districts, were placed separately in small plastic polythene bags and stored in the laboratory at $-20^{\circ} \mathrm{C}$ before subjecting to DAS-ELISA to test for specific viruses. Following the procedures described by Huguenot [14] and Shoyinka [15], the ELISA kits tested CABMV, CPCMV, CPMMV, CPMV, CPSMV, CMV and CCMV. In addition, the kits also contained positive and negative controls. Based on the manufacturer's instructions and the quantity of IgG provided, the microplate wells were coated with $100 \mu \mathrm{l}$ per well of virus specific IgG diluted at 1:1000 for CPMMV, CPMV, CPSMV and CMV, and $200 \mu \mathrm{l}$ per well diluted at 1:500 for CABMV, CPCMV and CCMV in $0.01 \mathrm{M}$ sodium carbonate buffer $\left(\mathrm{Na}_{2} \mathrm{CO}_{3}\right.$ and $\mathrm{NaHCO}_{3}, \mathrm{NaN}_{3}$ at $\mathrm{pH}$ 9.6) and incubated for $2-4$ hours at $37^{\circ} \mathrm{C}$. A cork borer was used to cut leaf disks of approximately $12 \mathrm{~mm}$ in diameter from the leaf base, middle and top sections of the leaf. The leaf disks were ground and diluted at $1: 10(\mathrm{w} / \mathrm{v})$ in $0.01 \mathrm{M}$ phosphate saline buffer, $\mathrm{PBS}\left(\mathrm{NaCl}, \mathrm{KH}_{2} \mathrm{PO}_{4}\right.$, $\mathrm{Na}_{2} \mathrm{HPO}_{4}$ and $\mathrm{KCl}, \mathrm{NaN}_{3}$ at $\mathrm{pH} 7.4$ ) containing $0.5 \mathrm{ml}$ Tween 20 (PBS-T) and $2 \%$ polyvinylpyrrolidone (PVP) and was incubated overnight at $4{ }^{\circ} \mathrm{C}$ covered with adhesive film. The positive and negative controls together with blank/buffer were each loaded in the duplicate wells. The immunoglobulin-alkaline phosphatase (IgG-AP) was diluted in PBS-T-PVP-egg albumin. Based on the manufacturer's instructions, the dilutions of IgG-AP varied with the type of virus and were as follows: IgG-AP was diluted at 1:1000 for CPSMV and CMV; 1:500 for CABMV, CPCMV, CPMMV, CCMV and CPMV in conjugate buffer (PBST, 2\% PVP containing $0.2 \%$ egg albumin (Sigma A-5253)). For dilution at 1:1000, $100 \mu \mathrm{l}$ were added to all wells, while for dilution at 1:500, 200 $\mu \mathrm{l}$ were added to all wells and incubated for 4 hours at $37^{\circ} \mathrm{C}$ covered with adhesive film. The $200 \mu \mathrm{l}$ aliquots of freshly prepared substrate [25 mg p-nitrophenyl phosphate, Pnpp (Sigma 104 - 105)], dissolved in $25 \mathrm{ml}$ of substrate buffer (diethanolamine, distilled water, $\mathrm{NaN}_{3}$ at $\mathrm{pH}$ 9.8) was added to all wells containing the bound IgG-AP and allowed to hydrolyse for 30 - 60 minutes at room temperature in order to obtain clear reactions of the yellow colour development. After adding the substrate buffer to each well of the ELISA microplates, they were incubated at room temperature for 90 minutes and visually observed the reactions and the wells that showed yellow coloration were considered positive, thus indicating the presence of that particular virus type. 


\section{Results}

\subsection{Incidence and Severity of Virus Symptoms on Cowpea Crop}

The results showed that there were highly significant $(\mathrm{P}<0.05)$ differences in incidence and severity of virus symptoms on cowpea crop in the surveyed districts and fields (Table 1). Similarly, a highly significant interaction effects $(\mathrm{P}<0.05)$ were also observed between farmers' fields and the districts. Virus symptoms were encountered in the four districts but with varying incidence levels of virus symptoms (Table 2). On average, the district of Kumi had consistently high incidence of virus symptoms in all the fields surveyed compared to Lira, Apac and Pader. Overall, there was a high disease incidence of $85.4 \%$ in Kumi district, followed by Lira with 75.3\%, with the lowest incidence recorded in the districts of Apac and Pader. A slightly lower disease severity was observed in all of the fields in the districts during the period of 2010 (Table 2). Significantly low disease severity was observed in Apac and Pader districts, respectively. The disease severity observed in the districts of Lira, Kumi and Pader did not differ significantly, but there was a higher disease level in Lira compared to the rest of the districts. It was observed that Apac district had a very low disease severity of $4.7 \%$ compared to Pader (11.8\%), Kumi (13.8\%) and Lira (14.5\%).

\subsection{Virus Detection by DAS-ELIS and Association in the Leaf Samples}

All the antibodies specific to virus type were tested and only four virus types namely CABMV, CPMMV, CMV and CPSMV were detected in the samples collected from the four districts in 2010 (Table 3). Thus, out of 112 samples collected, a total of 81 symptomatic samples with a percentage of $72.3 \%$ reacted positive to CPMMV

Table 1. Statistical analysis of incidence and severity of virus diseases in the fields grown with cowpea crop in four districts.

\begin{tabular}{cccc}
\hline & DF & \multicolumn{2}{c}{ Mean square } \\
\cline { 3 - 4 } Source & 3 & Incidence & Severity \\
\hline Replication & 3 & 185.0 & 102.5 \\
District (D) & 6 & $5126.3^{* * * *}$ & $560.3^{* * * *}$ \\
Fields (F) & 18 & $3919.0^{* * * *}$ & $157.9^{* * *}$ \\
D $\times$ F & 81 & $2845.0^{* * *}$ & $229.6^{* * *}$ \\
Residual & 235.0 & 32.7 \\
\hline
\end{tabular}

${ }^{* * * *}$ Data significant at $\mathrm{P} \leq 0.001$, fields $(\mathrm{F})=$ first, second, third, fourth, fifth, sixth and seventh; districts $(\mathrm{D})=$ Lira, Kumi, Apac and Pader.

Table 2. Mean percentage incidence and severity of virus symptoms in surveyed cowpea districts during 2010.

\begin{tabular}{|c|c|c|c|c|c|c|c|c|}
\hline \multirow{3}{*}{ Fields surveyed } & \multicolumn{4}{|c|}{ Mean percentage incidence of viral infection } & \multicolumn{4}{|c|}{ Mean percentage severity of viral infection } \\
\hline & \multicolumn{4}{|c|}{ Districts } & \multicolumn{4}{|c|}{ Districts } \\
\hline & Lira & Kumi & Apac & Pader & Lira & Kumi & Apac & Pader \\
\hline First & 89.7 & 90.2 & 67.9 & 94.4 & 12.5 & 7.5 & 7.5 & 18.8 \\
\hline Second & 76.5 & 89.7 & 82.2 & 20.8 & 8.8 & 13.8 & 5.0 & 8.8 \\
\hline Third & 86.6 & 84.0 & 81.3 & 92.2 & 15.0 & 7.5 & 5.0 & 20.0 \\
\hline Fourth & 29.4 & 96.0 & 66.5 & 88.2 & 6.3 & 20.0 & 6.3 & 4.3 \\
\hline Fifth & 88.3 & 59.3 & 51.8 & 97.2 & 22.5 & 6.3 & 4.3 & 17.5 \\
\hline Sixth & 96.0 & 100.0 & 34.9 & 16.0 & 22.5 & 35.0 & 3.5 & 3.0 \\
\hline Seventh & 60.7 & 78.3 & 6.5 & 15.6 & 13.8 & 6.3 & 1.3 & 2.0 \\
\hline Overall mean & 75.3 & 85.4 & 55.9 & 60.6 & 14.5 & 13.8 & 4.7 & 11.8 \\
\hline $\operatorname{LSD}_{(0.05)}$ & \multicolumn{4}{|c|}{21.6} & \multicolumn{4}{|c|}{8.0} \\
\hline CV\% & \multicolumn{4}{|c|}{22.1} & \multicolumn{4}{|c|}{51.2} \\
\hline
\end{tabular}


antibodies, making CPMMV the most prevalent virus in all the districts. This was followed by CABMV with a total of 41 symptomatic samples of percentage of $36.6 \%$ occurring in all the four districts. The CPSMV was detected in 39 symptomatic leaf plant samples giving a percentage of $34.8 \%$ obtained from all the four districts and 32 symptomatic leaf samples were detected giving a percentage of $28.6 \%$ that reacted positive to CMV antibodies.

A total of $13.4 \%$ of symptomatic plant leaf samples were detected with a single virus, whereas $10.7 \%$ of the plant leaf samples were found with association with other viruses (Figure 1). The most common and widespread virus infection in single association detected from the plant leaf samples was CPMMV with $11.6 \%$ and the least common was CABMV with 1.8\% (Figure 1). The CPMMV and CPSMV occurred in combination in the plant leaf samples with other viruses namely CMV and CABMV with 7.1\%. Similarly, combinations of viruses especially CPMMV and CPSMV occurred with 1.8\%, CMV and CPSMV with 0.9\%, CMV, CPMMV and CPSMV with $0.9 \%$ were detected interacting in the same plant leaf samples.

\section{Discussion}

The study established the prevalent identity of four cowpea viruses that are significantly important in cowpea growing districts of Uganda. The widespread distribution of virus infection on cowpea in the growing districts reported herein and the severe levels of infection, suggest that the viruses cause economical yield losses of cowpea. The results obtained in this study showed that there was a substantial occurrence of viruses during 2010. Considerable variations of incidence and severity of virus symptoms among the districts were observed. In all

Table 3. Detection of virus types tested serologically in symptomatic samples collected from four districts of Uganda during 2010.

\begin{tabular}{|c|c|c|c|c|c|c|c|c|}
\hline \multirow{2}{*}{ District } & \multirow{2}{*}{$\begin{array}{l}\text { Samples } \\
\text { tested }\end{array}$} & \multicolumn{7}{|c|}{ Virus serological detection with DAS-ELISA } \\
\hline & & CABMV & CPMMV & CPSMV & CMV & CPCMV & CPMV & CCMV \\
\hline Lira & 28 & $15(53.6)^{*}$ & 22 (78.6) & $16(57.1)$ & 12 (42.9) & - & - & - \\
\hline Kumi & 28 & $6(21.4)$ & 25 (89.3) & 9 (32.1) & $6(21.4)$ & - & - & - \\
\hline Арас & 28 & $4(14.3)$ & 24 (85.7) & 4 (14.3) & 4 (14.3) & - & - & - \\
\hline Pader & 28 & $16(57.1)$ & $10(35.7)$ & $10(35.7)$ & $10(35.7)$ & - & - & - \\
\hline Total & 112 & 41 & 81 & 39 & 32 & 0 & 0 & 0 \\
\hline
\end{tabular}

*Figures in parentheses are percentage incidence; - indicate no virus was detected in the samples in any of the districts.

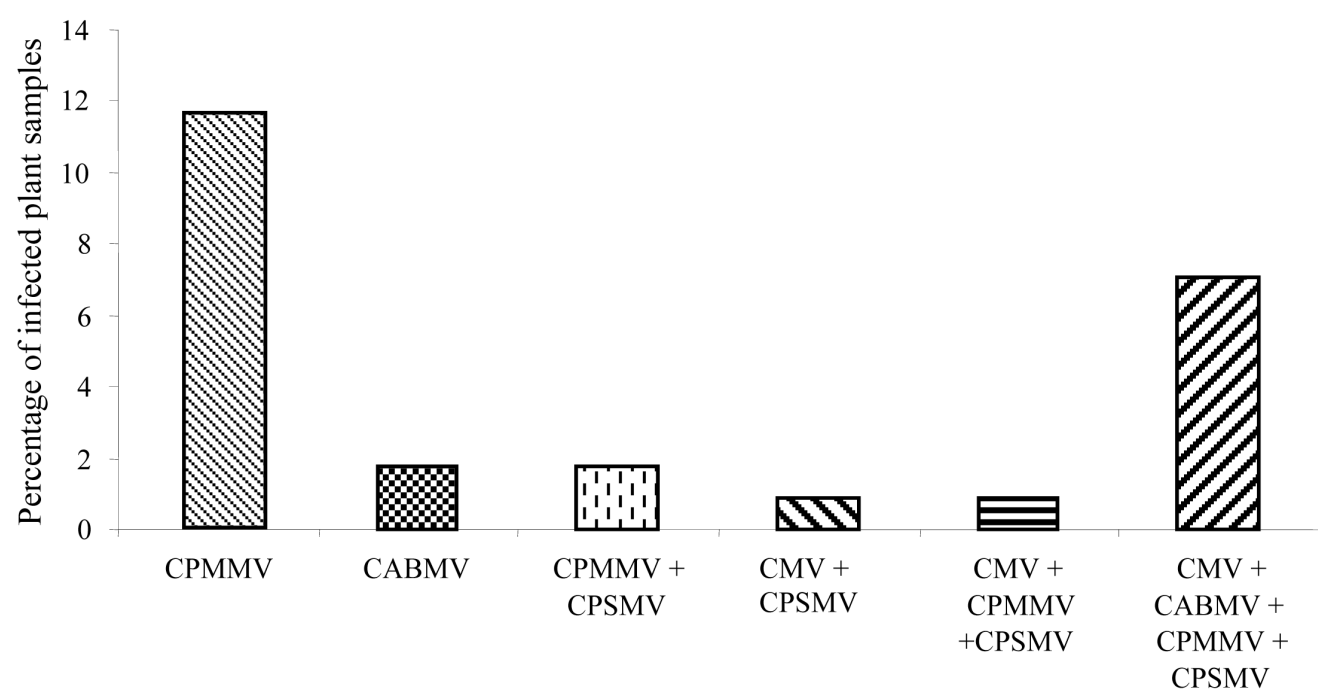

Figure 1. Percentage proportion of single virus and multiple viruses in the infected cowpea leaf samples in Apac, Lira, Kumi and Pader districts during 2010. 
the four districts surveyed, they exhibited virus symptoms with a higher incidence and severity in Kumi and Lira districts compared to Apac and Pader districts. A similar trend of virus symptoms was observed in all the fields surveyed in each district, with the exception of a few fields in Apac and Pader districts that registered low virus infection. In spite of the high virus incidence observed in the cowpea fields, it was generally moderate to high severity in all of the districts surveyed. However, there was a lower virus severity recorded in Apac district than in Lira.

The results obtained during surveys showed that virus diseases are widely distributed across the agro-ecological zones in the four districts. The overall incidence was $69.3 \%$ and $11.2 \%$ for severity. However, the extent and source of infection among the surveyed districts varied greatly during the season. Vacke [16] indicated that favourable climatic conditions can prolong vector migration, enhance vector population and consequently, increase their potential to transmit virus in wheat stands. Bukvayová [17] also attributed the epidemiology of vector-transmissible viruses to be related to weather conditions.

The virus severities identified are economically important which can intensify and cause great infection to cowpea crops, resulting from progression of virus vector populations and consequently, increase the inoculum level to cause high virus incidence in fields of cowpea. Shoyinka [15] and Edema [18] attributed virus variability to be due to changes in weather conditions within seasons and farming systems in the different environments. Perennial and weed hosts have also been shown to be important in the ecology of several viruses [19] [20]. The large populations of the virus vectors are usually found on the weeds, particularly during the second growing season, which may account for the greater population of aphids that transmit cowpea virus [21].

The four virus types CABMV, CPSMV, CPMMV and CMV identified in Apac, Kumi, Lira and Pader districts suggest their existence in the major cowpea growing areas of Uganda. It is also showed that some viruses were associated in single or multiple infection(s) in the plant leaves. The plant leaf samples had a high prevalence of single virus infection compared with multiple virus infection. In single virus-infected leaf samples, CPMMV was the most common, while CABMV was the second and least common during the year of survey. In multiple infected plants, a combination of CMV, CABMV, CPMMV and CPSMV was the highest and the most common, followed by CPMMV and CPSMV while CMV and CPSMV, and CMV, CPMMV and CPSMV occurred at low percentages in the plant leaf samples. These differences in the levels of occurrence of a particular virus being common in one sample and not in the other samples may be explained on the basis of antagonism, inoculum level, age of the plant, climatic conditions and cultivar type [22]. Studies have shown that the presence of viruses in a combination may result in synergism or antagonism effects within the infected plants. For instance, viruses acting in synergistic manner enhance their infection rate, thus leading to the development of complexes of diseases [8] [23]. Sakai [4] reported that some viruses may be antagonized when in a combination with other viruses, and their rate of infection may be affected compared with single virus infection. The higher infection of plants by CPSMV in the samples compared to CPMMV and CABMV could suggest its relative persistence under adverse environmental conditions over the other viruses. However, there was no association between CPMMV and CABMV alone in the cowpea samples. Therefore, this study identified CABMV, CPMMV, CPSMV and CMV as being the most important viruses affecting cowpea in Uganda. Since the four viruses are the most common and widespread viruses detected, it is signified that there is a need to have concerted effort to develop breeding strategy for cowpea resistant varieties to manage the multiple viruses. These findings on the occurrence and detection of CABMV confirmed the study by Edema [18], and indicated CABMV becoming important which is likely to cause great damages to cowpea production. However, it may not be valuable to select for CABMV resistance without taking into account for the other viruses detected, because their high incidences, severities and their interactions to one another in the crop may cause great impacts on yield losses of cowpea.

The findings of the study revealed four important viruses infecting cowpea in the surveyed districts in Uganda. However, this study did not carry out a wide coverage to other cowpea growing districts in different regions due to limited resources. It is important to conduct such a study in other regions to understand the distribution and prevalence of similar and other virus types. This will enable to determine other virus types that may exist in those regions that have diverse agro-ecologies since knowledge on different virus types is essential in breeding for multiple resistances. This is intended to avoid the phenomenon of the "boom and bust" virus resistance due to emerging different strains of viruses. The study also observed that using DAS-ELISA is a sensitive and reliable test for plant viruses but its procedures are laborious and time-consuming for one to obtain results compared 
with other methods such as polymerase chain reaction which is very sensitive for detecting a number of plant viruses.

\section{Acknowledgements}

This study was funded by the Alliance for a Green Revolution in Africa (AGRA), Nairobi, Kenya grant number 2007 PASS 013. We also thank the National Semi-Arid Resources Research Institute for providing the facilities to conduct research work. The antisera used for serological testing were procured through Dr. S. Max from Deutsche Sammlung von.

\section{References}

[1] Ehlers, J.D. and Hall, A.E. (1997) Cowpea (Vigna unguiculata (L.) Walp.). Field Crops Research, 53, 187-204. http://dx.doi.org/10.1016/S0378-4290(97)00031-2

[2] FAO (1997) Production Yearbook. Food and Agriculture Organisation of the United Nations, Rome, 98.

[3] Orawu, M. and Obuo, J.P. (2008) Baseline Survey on Cowpea Production, Utilisation and Constraints in Northern and Eastern Regions of Uganda. Technical Report, Grain Legume Improvement Program, Serere, No. 3, 13.

[4] Sakai, F., Dawson, J.R.O. and Watts, J.W. (1983) Interference in Infections of Tobacco Protoplasts with Two Bromoviruses. Journal of General Virolology, 64, 1347-1354. http://dx.doi.org/10.1099/0022-1317-64-6-1347

[5] Tarawali, S.A., Smith, J.W., Hiernaux, P., Singh, B.B., Gupta, S.C., Tabo, R., Harris, F., Nokoe, S., Fernandez-Rivera, S. and Bationo, A. (2000) Integrated Natural Resource Management-Putting Livestock in the Picture. Integrated Natural Resource Management Meeting, Penang.

[6] Byoung-Cheorl, K., Inhwa, Y. and Molly, M.J. (2005) Genetics of Plant Virus Resistance. Annual Review of Phytopatholology, 43, 581-621. http://dx.doi.org/10.1146/annurev.phyto.43.011205.141140

[7] Alegbejo, M.D. and Kashina, B.D. (2001) Status of Legume Viruses in Nigeria. Journal of Sustainable Agriculture, 18, 55-69. http://dx.doi.org/10.1300/J064v18n01_05

[8] Vance, V.B., Berger, P.H., Carrington, J.C., Hunt, A.G. and Shi, X.M. (1995) Five Proximal Potyviral Sequence Mediates Potato Virus X/Potyviral Synergistic Disease in Transgenic Tobacco. Virology, 206, 583-590. http://dx.doi.org/10.1016/S0042-6822(95)80075-1

[9] Hampton, R.O. (1983) Seed-Borne Viruses in Crop Germplasm Resources: Disease Dissemination Risks and Germplasm-Reclamation Technology. Seed Science and Technology, 11, 525-546.

[10] Catalina, G.L. and Elena-Cocuta, B. (2012) Validation of DAS-ELISA Results for the Detection of Grapevine Fleck Virus. Journal of Horticulture, Forestry and Biotechnology, 16, 57-61.

[11] Boscia, D., Digiaro, M., Fresno, J., Greif, C., Grenan, S., Kassemeyer, H.H., Prota, V.A. and De Sequueira, O.A. (1997) ELISA for the Detection and Identification of Grapevine Viruses. In: Walter, B., Ed., Sanitary Selection of the Grapevine, INRA Editions, Colmar (France), Les Colloques, 86, 129-155.

[12] Guatelli, J.C., Gingeras, T.R. and Richman, D.D. (1989) Nucleic Acid Amplification in Vitro Detection of Sequence with Low Copy Numbers and Application to Diagnosis of Human Immunodeficiency Virus Type 1 Infection. Clinical Microbiology Review, 2, 217-220.

[13] Ndunguru, J. and Jeremiah, S.C. (1999) Cassava Mosaic Disease Status in Bukoba and Karagwe Districts. Technical Report, OFDA CMD Project, IITA-ESARC, Kampala.

[14] Huguenot, C., Furneaux, M.T., Thottappilly, G., Rossel, H.W. and Hamilton, R.I. (1993) Evidence That Cowpea Aphid-Borne Mosaic and Blackeye Cowpea Mosaic Viruses Are Two Different Potyviruses. Journal of General Virology, 74, 335-340. http://dx.doi.org/10.1099/0022-1317-74-3-335

[15] Shoyinka, S.A., Thottappilly, G., Adebayo, G.G. and Anno-Nyako, F.O. (1997) Survey on Cowpea Virus Incidence and Distribution in Nigeria. International Journal of Pest Management, 43, 127-132. http://dx.doi.org/10.1080/096708797228816

[16] Vacke, J. (1983) Survival and Spreading of Wheat Dwarf Virus through the Seasonal Cycle. Proceedings of the 9th Czechoslovak Plant Protection Conference, Brno, 30 August-1 September 1983, 234-236.

[17] Bukvayová, N., Henselová, M., Vajciková, V. and Kormanová, T. (2006) Occurrence of Dwarf Virus of Winter Wheat and Barley in Several Regions of Slovakia during the Growing Seasons. Plant Soil Environment, 9, 392-401.

[18] Edema, R., Adipala, E. and Florini, D.A. (1997) Influence of Season and Cropping System on the Occurrence of Cowpea Diseases in Uganda. Plant Disease, 81, 465-468. http://dx.doi.org/10.1094/PDIS.1997.81.5.465

[19] Duffus, J.E. (1971) Role of Weeds in the Incidence of Virus Diseases. Annual Review of Phytopathology, 9, $319-340$. 
http://dx.doi.org/10.1146/annurev.py.09.090171.001535

[20] Thresh, J.M. (1974) Temporal Patterns of Virus Spread. Annual Review of Phytopathology, 12, 111-128. http://dx.doi.org/10.1146/annurev.py.12.090174.000551

[21] Atiri, G.I., Enobakhare, D.A. and Thottappilly, G. (1986) The Importance of Colonizing and Non-Colonizing Aphid Vectors in the Spread of Cowpea Aphid-Borne Mosaic Virus in Cowpea. Crop Protection, 5, 406-410. http://dx.doi.org/10.1016/0261-2194(86)90073-6

[22] Wisler, G.C., Duffus, J.E., Liu, H.Y. and Li, R.H. (1998) Ecology and Epidemiology of Whitefly-Transmitted Closteroviruses. Plant Disease, 82, 270-280. http://dx.doi.org/10.1094/PDIS.1998.82.3.270

[23] Fondong, V.N., Pita, J.S., Rey, M.E., de Kochko, A., Beachy, R.N. and Fauquent, C.M. (2000) Evidence of Synergism between African Cassava Mosaic Virus and a New Double-Recombinant Geminivirus Infecting Cassava in Cameroon. Journal of General Virology, 81, 287-297. 